\title{
A DIVERSIDADE RELIGIOSA E NÃO RELIGIOSA NAS CATEGORIAS CENSITÁRIAS DO IBGE E SUAS LEITURAS NA MÍDIA E PRODUÇÃO ACADÊMICA ${ }^{1}$
}

\author{
Paula Montero ${ }^{2}$ \\ Henrique Fernandes Antunes ${ }^{3}$
}

Resumo: Este artigo tem como ponto de partida o interesse recente que os dados censitários sobre a religião e os sem religião suscitaram na grande mídia, em particular nos dois jornais impressos de maior circulaçáo no país, a Folha de São Paulo e o Estado de São Paulo. Também examinaremos a natureza desse interesse e suas implicaçóes ao longo destas últimas décadas no âmbito acadêmico. Tendo em vista que o Estado brasileiro tem uma política censitária profissional e regular desde a década de 1940, analisaremos o debate em torno das modificaçôes das categorias censitárias sobre a religiáo nos últimos levantamentos entre pesquisadores e o IBGE. Tomaremos essa variação categorial como indicativo de uma mudança progressiva da sensibilidade pública e acadêmica com relação à diversidade religiosa e à não religiáo.

Palavras-chave: Diversidade; Censo; Mídia; Produção Acadêmica.

\section{RELIGIOUS AND NON-RELIGIOUS DIVERSITY IN IBGE'S CENSUS CATEGORIES IN THE MEDIA AND ACADEMIC LITERATURE}

\begin{abstract}
The starting point of this article is the recent interest that census data on religion and nonreligion promote in the mainstream media, particularly in the two

${ }^{1}$ Como citar: MONTERO, Paula; ANTUNES, Henrique Fernandes. A diversidade religiosa e não religiosa nas categorias censitárias do IBGE e suas leituras na mídia e produçáo acadêmica. Debates do NER, Porto Alegre, v. 2, n. 38, p. 339 - 373, 2020.

2 Doutora em Antropologia pela Universidade de São Paulo, Brasil. Professora titular da Universidade de São Paulo, Brasil, e pesquisadora do Centro Brasileiro de Análise e Planejamento, Brasil. E-mail: pmontero@usp.br.

${ }^{3}$ Pós-doutorando - International Postdoctoral Program, Centro Brasileiro de Análise e Planejamento (CEBRAP), Brasil. E-mail: hictune@yahoo.com.
\end{abstract}


most widely circulated printed newspapers in the country, Folha de São Paulo and O Estado de São Paulo. We will examine the nature of this interest and its implications over the past decades in the academic field. Given that the Brazilian state has had a regular census policy since the 1940s, we will analyze how census categories on religion have changed in recent surveys with the collaboration of researchers and scholars. We will take this categorical variation as indicative of a progressive change in public and academic sensitivity to religious and nonreligious diversity.

Keywords: Diversity; Census; Media; Academic Literature.

\section{A DIVERSIDADE RELIGIOSA E NÃO RELIGIOSA NAS CATEGORIAS CENSITÁRIAS DO IBGE NA MÍDIA E PRODUÇÃO ACADÊMICA ${ }^{4}$}

Os números adquiriram, como se sabe, um indiscutível poder de persuasão na cultura política moderna, servindo de medida de sucesso de um governo e de parâmetro do que deve ser governado. Os dados de desenvolvimento econômico são acompanhados de perto pelos especialistas. A melhora ou piora dos índices de saúde, educação e renda são motivo de otimismo ou preocupação. Mas não é apenas o desenvolvimento das condiçôes econômicas de uma nação que interessam ao Censo. Também importam o comportamento e a composição da população. Naturalizou-se como padrão internacional o levantamento, pelos Censos, do tamanho da população, sua distribuição, taxas de fecundidade, mortalidade, formas

${ }^{4}$ Este trabalho é resultado do Projeto Temático Religião, Direito e Secularismo (2015/024975), financiado pela Fapesp, cujo apoio agradecemos. Ele também é parte do esforço coletivo de uma equipe composta por Dirceu André Girardi, Camila Nicácio, Rafael Quintanilha, Henrique Antunes e Paula Montero que, em parceria com o projeto Nonreligion in a Complex Future, coordenado por Lori Beaman (University of Ottawa), empreendeu em 2019 um amplo levantamento sobre a literatura existente acerca do tema dos "sem religião" no Brasil.

Debates do NER, Porto Alegre, ano 20, N. 38, P. 339-373, Ago./Dez. 2020 
de nupcialidade e modos de organização do núcleo familiar, entre outros grandes temas relativos à sua demografia.

As categorias censitárias incluídas nesses esforços estatísticos, no entanto, sempre variaram segundo os países, os governos e os contextos políticos. Sua inclusão ou exclusão, ao mesmo tempo, expressa e consolida um certo modo, política e ideologicamente informado, de retratar uma nação. No que diz respeito à categoria censitária "religiâo", chama nossa atenção que, ao contrário de muitos países, como por exemplo Estados Unidos 5 , Inglaterra, França e Argentina, ela tenha permanecido, com poucas interrupçóes ${ }^{6}$, uma descritora essencial da dinâmica demográfica brasileira desde o primeiro Censo nacional ainda no período imperial (1870), sem jamais despertar oposição da sociedade. Apesar de constante, foi também um dos indicadores cujas subcategorias internas mais variaram.

Neste artigo examinaremos como e em que termos os resultados relativos ao tópico da religiáo dos brasileiros, atraíram a atenção de parte da grande imprensa nos últimos Censos e como impactaram a reflexão acadêmica. Partimos do suposto que, examinando as narrativas oferecidas por esses órgáos de imprensa, poderemos compreender como a diversidade religiosa e a não religião é imaginada por esses formadores de opinião e de que modo interpelam sua audiência. Ao mesmo tempo, a partir de uma análise dos trabalhos acadêmicos que se ocuparam dos Censos, veremos que esses levantamentos fizeram emergir um novo olhar sobre a diferença religiosa.

\section{OS CENSOS NA MÍDIA}

Até muito recentemente os resultados dos levantamentos censitários não eram matéria de muito interesse jornalístico. Os números interessavam

\footnotetext{
${ }^{5}$ Nos Estados Unidos a Suprema Corte proíbe que essa questão conste nos levantamentos censitários.

${ }^{6}$ Não houve levantamento censitário em 1910 e em 1930. O quesito religião foi omitido no Censo de 1920 e o de cor nos Censos de 1900, 1920 e 1970.
} 
mais aos especialistas, gestores e alguns setores da academia. A partir de 2000, contudo, os dados do Censo passaram a merecer mais atenção da mídia. Nadya Miguel (2012, p. 81) credita essa nova disposição à incorporação pelo IBGE de modernas tecnologias que passaram a permitir uma disseminação mais ampla, fácil e rápida das informações censitárias. Além disso, o Instituto de Estatística também promoveu atividades de divulgação e publicidade para sensibilizar o grande público sobre a importância desse levantamento. Para a divulgação dos dados preliminares do Censo de 2000, organizou-se, por exemplo, um evento em 2002, transmitido via satélite, no qual foram resumidos os resultados referentes a cinco temas: religião, portadores de deficiência, educação, domicílios e mortalidade infantil. Segundo os organizadores: "foram mais de cinco horas de IBGE nas principais redes de televisão do país, em noticiários, entrevistas e outros programas" (Revista do Censo, 2002, p. 5).

Uma das resultantes desse novo tipo de publicidade dado às religióes é, como bem observou Mafra (2013a, p. 13), seu uso político. Entre outras coisas, os números passaram a servir de apoio para alianças eleitorais, conferindo peso e importância às igrejas mais populosas. Ainda que essa questão mereça atençáo, o que nos interessa analisar neste inciso não são os usos políticos das estatísticas, mas o modo como as notícias dos jornais narram essas cifras sobre as religiôes e lhes conferem sentido. Trata-se de capturar o olhar da mídia sobre esse fenômeno recente que é a diversidade religiosa, evidenciada nos dois últimos Censos. Partimos do suposto que a análise das narrativas jornalísticas nos permite apreender em que termos a diversidade religiosa e não religiosa tornaram-se, para a mídia, um problema de interesse público. Embora muitos estudiosos tenham se debruçado sobre os resultados dos Censos e sua interpretação pelas lideranças religiosas e pela academia (Camurça 2006), no conjunto de mais de sessenta títulos compulsados para este trabalho, apenas um artigo se ocupou, de maneira mais sistemática, em analisar os modos de narrar a diversidade religiosa e não religiosa nas reportagens e editoriais da grande imprensa e na mídia religiosa. Em publicação de 2013, Emerson Giumbelli descreve como os jornais $O$ 
Estado de São Paulo e O Globo noticiam os dados censitários de 2010 sobre religião. $\mathrm{O}$ autor dá destaque aos mapas, gráficos e diagramas elaborados pelos jornais para traçar o perfil dos adeptos das várias religiôes. Ao lado disso, conclui que a maior parte das matérias concentram sua atenção nos números relativos ao crescimento evangélico e ao correspondente declínio do catolicismo (Giumbelli 2013).

Tomando como referência esse destaque dado pela imprensa ao declínio do catolicismo, que também aparece no material analisado por nós, nosso objetivo aqui é analisar, nas narrativas jornalísticas, os afetos, as imagens e percepçóes que essa reiterada constataçáo suscitou. Interessa-nos mais sua dimensão ficcional do que objetiva. Por que esse declínio suscitou tanto interesse? Para quem, como e em que termos ele representa um problema? Que tipo de apreensôes e imagens de futuro esse retrato fomentou? Como esses números dáo forma a uma imaginaçáo de nacionalidade? Como afetam a representaçáo da natureza moral do casamento? Essas foram algumas das perguntas que orientaram nossa reflexão. Para tanto, apoiamos nossa análise no trabalho de André Girardi que levantou as reportagens sobre os dois últimos Censos nos portais jornalísticos da Folha de São Paulo e Estado de São Paulo, os websites de maior alcance no país devido a sua ampla cobertura editorial, bem como pelo seu farto conteúdo disponível ${ }^{7}$. A partir de métodos informáticos, que consideram grupos de palavras-chave ${ }^{8}$, foram capturados o título, o lead, o texto, entre outras informaçóes, de milhares de artigos, possibilitando a composição de um banco de dados relativo ao período 2000-2019. Em processo posterior foi aplicado um método de filtragem de dados a fim de recortar os casos relacionados à temática dos

${ }^{7}$ O trabalho segue o código de ética de webscraping na internet. Disponível em $<$ https:// www.folha.uol.com.br/robots.txt $>$ e $<$ https://www.estadao.com.br/robots.txt $>$.

8 Os termos da pesquisa foram os seguintes: "sem religião", "não religião", "agnóstico", "ateu”, "agnosticismo”, “ateísmo”, "charlatanismo", "curandeirismo”, “iconoclasta”, "laicidade", "laicismo". 
Censos no Brasil que resultou em pouco mais de uma centena de artigos. Dentre esses artigos privilegiamos os que tinham como tema a religião.

Apesar da amplitude temporal o conjunto perfaz apenas 62 reportagens, com uma inserçáo média de uma a três notícias por ano. $\mathrm{O}$ ano de 2012, no entanto, quando começam a sair os primeiros resultados do Censo de 2010, concentrou a atenção da imprensa que, em nossa amostra, publicou 22 reportagens sobre o tema. Demos particular atençâo às manchetes e sua reiteração, em específico à imagem do declínio do catolicismo e as ansiedades que ele parece provocar. Interessou-nos capturar os diversos discursos que os números sobre esse declínio mobilizam e as definiçôes de responsabilidade sobre esse fato. Observaremos a seguir que, em sua dimensão narrativa, o esfacelamento da maioria política, a mudança no caráter aglutinante das identidades locais e nas formas tradicionais de casamento foram as resultantes mais diretas e reiteradamente associadas ao topos do declínio da hegemonia católica.

\section{A. Religióes e maiorias}

Ao percorrermos o conjunto de manchetes que procuram capturar a atenção do público nesse conjunto de matérias, nota-se a emoção, o tom quase dramático, com que se anuncia o declínio do contingente católico no país. Chamadas como Proporçāo de católicos é a menor em quase 140 anos (23/08/2011 ESP), Igreja Católica tem queda recorde e perde 465 fiéis por dia em uma década (30/06/2012 ESP), Nordeste e Sul são os últimos "bastiôes" católicos do Brasil (29/06/2012 ESP), ou ainda Católicos passam de 93,1\% para 64,6\% da população em 50 anos, aponta IBGE (29/06/2012 FSP), indicam que a diminuiçáo do número de pessoas que se declaram católicas é percebida como uma significativa ruptura com o passado histórico da sociedade brasileira. A marcação temporal nessas manchetes é bem significativa: a magnitude da mudança e sua inexorável aceleração no momento presente é medida por um balizamento temporal - "menor em quase 140 anos", "queda recorde e perde 465 fiéis por dia em uma década" e "64,6\% 
da população em 50 anos". Ainda que as manchetes não tenham lançado mão de nenhum adjetivo para qualificar esse decréscimo populacional, as metáforas relativas à proporção dessa população e à rapidez de seu decréscimo no tempo são suficientes para comunicar ao leitor que, embora os católicos "resistam, essa tendência é inexorável", a sociedade brasileira de amanhã não será mais igual ao seu passado.

Pode-se apenas conjecturar como essas declaraçóes impactam na imaginaçáo do leitor. Sabemos que a imagem do Brasil "como a maior naçáo católica do mundo", por muitas razóes, tornou-se parte de nosso senso comum. Percebe-se, portanto, um certo desassossego e alguma incerteza nesta perspectiva de um futuro náo católico e, como veremos a seguir, mais evangélico e, até mesmo, não religioso. De um modo geral, o anúncio do decréscimo populacional dos católicos sempre vem acompanhado da constataçáo do rápido crescimento da proporção dos evangélicos e dos que se dizem sem religiấo. Na verdade, é na associação desses três movimentos articulados entre si que se situa o núcleo da notícia, como se pode ver no exemplo abaixo:

Em relação à religiosidade, o Censo 2000 captou uma mudança significativa. Embora continue a ser um País majoritariamente católico, a proporção de fiéis da Igreja Católica caiu de 83,8\% da populaçáo para 73,8\%. Uma queda de $12 \%$. Ao mesmo tempo, houve um crescimento de evangélicos e de pessoas que se declararam sem religião (8/5/2002 ESP) (grifos nossos).

É a alteração na proporção relativa dos contingentes demográficos das religióes entre si e das religióes com a não religião que é percebida aqui como significativa. Essa dinâmica parece colocar uma pitada de incerteza em nossa visão do futuro. Embora as implicaçôes políticas e morais dessa variação não tenham sido explicitadas nas notícias, pode-se supor que elas remetem à percepção de uma oscilação, real ou imaginária, no equilíbrio de forças entre os grupos, determinada pelo simples aumento ou declínio da densidade relativa entre as populaçóes. Neste enquadramento não há espaço 
para o vácuo. Se a densidade populacional das "religiôes" em geral declina, cresceria a densidade da "não religião". Além disso, observa-se que, ao usar a adversativa embora, o texto destaca a perda de influência do segmento católico e, ao enfatizar o tamanho de sua queda, sugere um sentimento de apreensão com relação a uma inversão de tendência que poderia estar bem próxima. A reiterada ênfase nessa inflexão expressa sub-repticiamente o senso de uma divergência incomensurável ou contradição incontornável entre as visóes de mundo, crenças e objetivos desses diferentes grupos.

É preciso lembrar que um dos efeitos ideológicos próprios desse tipo de levantamento estatístico é produzir, por meio das operaçôes de nomeação e quantificação de indivíduos agrupados em uma determinada categoria, a reificação ontológica dessas categorias em grupos corporificados de crenças e interesses compartilhados. Veremos adiante que a linguagem comum, recorrentemente, associa a maior densidade populacional de um grupo ao conceito político de maioria. Não é outro o sentido contido na reiteração da ideia de que o Brasil é majoritariamente católico. Ora, como bem observou o cientista político Stephan Kraut (1999), o princípio da maioria é um método de tomada das decisóes nas democracias contemporâneas. O princípio do maior número diz respeito a mecanismos formais de produção de decisões políticas quando não há consenso estabelecido sobre uma determinada questão. As maiorias demográficas não se constituem, por si só e automaticamente, em maiorias políticas. No mais das vezes, as maiorias políticas resultam de uma rede de compromissos não necessariamente coerentes ou coalizóes de interesses pontuais, o que as torna, portanto, instáveis e eventuais. Para o autor, é essa instabilidade das maiorias que, ao promover sua alternância, lhes garante legitimidade. ${ }^{9}$

9 Segundo Stephan Kraut (1999), em sociedades muito heterogêneas, constituídas de minorias sem qualquer chance de vir a tornar-se maioria, o alcance das decisóes políticas tomadas pela maioria começa a ter sua legitimidade contestada. Assim, a existência de minorias étnicas, linguísticas, culturais e religiosas duradouras em uma dada sociedade começa a ser percebida na prática constitucional como uma importante limitação à aplicação do princípio da maioria para a tomada de decisóes.

Debates do NER, Porto Alegre, ano 20, N. 38, P. 339-373, Ago./Dez. 2020 
Assim, ainda que as maiorias políticas não possam ser consideradas resultantes automáticas das maiorias demográficas, percebe-se que a reiterada afirmação sobre o crescimento numérico dos evangélicos nessas reportagens, evoca e consolida a imagem dessa equivalência. "No Brasil, o Censo 2010 mostrou que o número de evangélicos continua avançando, enquanto o de católicos perde peso", informa notícia do Estado de São Paulo (29/06/2012, grifos nossos), enquanto a Folha destaca que "[...] os evangélicos representam hoje o dobro do que eram há dez anos. Já a Igreja católica, que continua sendo a maior do país, viu sua influência cair" (08/05/2002 FSP, grifos nossos). De um lado, a escolha de expressões tais como "perder peso", "avançar", "influência”, para descrever a evidência numérica do crescimento evangélico, implicitamente associa a imagem de sua densidade populacional à figura de uma maioria política. De outro, a mudança nessas proporçóes se associa, nessa narrativa, às incertezas suscitadas pelos ainda inexplícitos interesses ou valores dessas potenciais novas maiorias demográficas. Alguns entrevistados, como o pastor luterano Nestor Paulo Fredrich, vocalizam esse desconforto afirmando que "[...] criou-se no imaginário brasileiro um senso comum superficial de que o segmento evangélico está aí para a exploração da boa fé do povo. Embora isso até possa ter base de realidade, a questão é mais complexa. Não se pode generalizar" (FSP 31/10/2017).

Indo um pouco mais longe nessa associação entre densidade demográfica e representação política, a maioria estatística também é imaginada em termos de sua potencialidade eleitoral. "RJ é o primeiro a ter estado e capital governado por partidos 'cristãos” (FSP 01/11/2018), anuncia a manchete da Folha de São Paulo. Citando o Pastor Everaldo, a matéria indica que "o estado lidera o declínio católico e o avanço evangélico e dos sem religião nas últimas décadas. É natural que, com a mobilização política de algumas igrejas evangélicas, eles ampliem sua representação". Nota-se, portanto, que a narrativa midiática reforça uma correlação entre o crescimento numérico e fortalecimento político fazendo acompanhar o interesse com relação aos novos pertencimentos religiosos de uma inquietaçáo a respeito de seus impactos na representatividade política. 
B. Religióes, cultura E identidades

Associadas a essa retórica dos grandes números, as matérias também reiteram, como uma curiosidade que vale a pena conhecer, a distribuição geográfica dessas maiorias. Assim, ficamos sabendo que o "Piauí é o Estado que concentra a maior proporção de católicos" (ESP 29/06/12), "Rondônia o mais evangélico" (FSP 29/06/2012), que o Rio de Janeiro "é o estado que lidera o declínio católico e o avanço evangélico e dos sem religião" (ESP 01/11/2018), que "Palmelo, [em Goiás], tem a maior proporção de espíritas" (ESP 29/06/2012), que o Censo de 2010 "derrubou o mito de que a Bahia é o Estado da Umbanda e Candomblé” (ESP 29/06/2012), que o Chuí lidera nas estatísticas dos "moradores que se declaram sem religiaao" (ESP 29/06/2012; FSP 15/07/2012), e que o Estado do Rio Grande do Sul "chama atenção no país por reunir os municípios com maior concentração relativa de católicos, evangélicos, umbandistas e candomblecistas, além de pessoas sem religião" (FSP 29/06 2012).

Difícil afirmar com certeza o que realmente importa neste pequeno exercício de mapeamento de maiorias demograficamente táo desiguais como, por exemplo, as do Piauí e da Bahia. É claro que, quando o levantamento das diferenças regionais em termos religiosos indica que "os católicos se concentram nos pequenos municípios e os evangélicos nos grandes centros" (ESP 20/12/2002), novamente está sendo evocado aqui o declínio do peso da igreja católica, em termos de sua capacidade de controle da vida das famílias nas grandes cidades. Essa retórica relacional, utilizada na narrativa para descrever as religióes nas cidades e/ou Estados - "a que concentra", "a maior proporção", "que lidera" -, evoca a imagem de que cada religiáo emprestaria um caráter, até mesmo uma tradição particular, a uma determinada população regional: o espiritismo parece definidor da vocação da cidade de Palmelo; a concentração de moradores sem religião em Goiás e Chuí é relatada como um fato surpreendente. A manchete sobre a Bahia é a mais reveladora dessa percepção, ainda que a contradiga: a notícia de que o Censo de 2010 teria derrubado o mito de uma maioria afro religiosa 
nesse Estado. Esse dado confrontaria o senso comum que associa as religióes afro-brasileiras à cultura/identidade da população negra. Rio Grande do Sul é destacado como um estado particular, quando comparado aos outros, em razão de sua grande heterogeneidade religiosa: ele é o único a reunir municípios que concentram maiorias relativas de católicos, evangélicos, religióes afro e sem religião. Os leads jornalísticos tratam essa particularidade em termos de "liderança estatística",

Os pequenos municípios gaúchos lideram várias estatísticas do Censo. Arroio do Padre, no sul do Estado, com 2,7 mil habitantes, tem o maior índice do País de moradores evangélicos $(85,8 \%)$ e o menor de católicos $(7,8 \%)$. Dos dez municípios brasileiros com maior índice de católicos, nove estão no Estado. Dos dez que têm maiores percentuais de evangélicos, sete são gaúchos. E não é só. Os dez municípios com maiores índices de seguidores de umbanda e candomblé estão no RS, Chuí é o líder entre os sem religião (ESP 30/06/2012).

O estado é evocado como um "experimento social” em miniatura no qual as populaçóes de diferentes tradiçóes religiosas e as que não têm religiáo conviveriam em harmonia. Essa diversidade de pequenas maiorias é imaginada em termos de "contrastes" (ESP 29/06/2012) e não de "conflitos", talvez porque as densidades populacionais em jogo sejam, neste caso, bastante diminutas. Também a cidade de São Paulo, com seus números de ateus e judeus, chama a atenção da imprensa por sua diversidade religiosa. Novamente essa diversidade é evocada, explicitamente, em associação com a chave da cultura.

Ateus chegam a 70 mil em São Paulo; judeus são 43 mil” (ESP 07/07/2012); "os números do Censo refletem a diversidade cultural e religiosa da capital paulista. Além da explosão de espíritas, que formam o quarto grupo religioso de São Paulo (530 mil pessoas), outras religióes tradicionais têm representatividade, como a dos adeptos do budismo (66,5 mil), da umbanda (51 mil), do judaísmo (43 mil) e do islamismo (8 mil). Também chama a atenção o número de ateus (70 mil) e de agnósticos (21 mil) (ESP 08/07/2012). 
Já a população dos sem religião, embora retratada como uma "minoria absoluta" (ESP 29/06/2012), recebeu enorme atenção da imprensa em razão de seu crescimento de "70\% em vinte anos". Além de ser uma novidade para uma sociedade como a brasileira, em que as religiōes são muitas e sempre consideradas virtuosas, a rapidez de seu crescimento recente impressionou, foi muitas vezes mencionada e exigiu explicaçôes. Reverbera nas manchetes uma certa ansiedade com relação à antecipação de um futuro sem religiáo. Apoiadas em entrevistas com religiosos e acadêmicos, as reportagens se apressam a esclarecer que "a religião não vai acabar" (colunista Hélio Schwartsman FSP 18/08/2011) e que as "pessoas que se dizem sem religião não são necessariamente ateias" ( $\mathrm{PF}$ da PUC/SP Frank Usarski FSP 13/12/2015), que "não ter religiáo não significa, necessariamente, falta de religiosidade" (antropólogo Ronaldo de Almeida FSP 14/12/2003) e ainda que "declarar-se sem religiáo não significa, necessariamente, a rejeição à fé" (Pastor Nestor Paulo Friedrich FSP 31/10/2017).

Interessantemente, enquanto os outros grupos sáo trabalhados em termos de uma gramática preponderantemente estatística, os números dos "sem religiáo" vêm, muitas vezes, acompanhados de uma narrativa que dá nome e humaniza a experiência de um indivíduo que "perdeu a vergonha de dizer" publicamente, (ESP 24/08/2011) ou de se declarar não religioso no Censo. Assim, ficamos sabendo que "uma jovem publicitária, Aline Rodrigues Vieira Pinto, sem religiáo, faz em casa, uma vez por mês, 150 marmitas para quem vive embaixo de um viaduto na zona norte" (FSP 29/01/2017) e que:

Sem religião, a estudante de turismo Alessia Isabella Nemichini, de 20 anos, diz que até tentou ser católica. A moça, que não foi batizada porque a mãe acredita que não se deve impor a religiáo, chegou a frequentar encontros de jovens católicos. Mas desistiu [...]. Se você tem uma família que ensina o que é correto, o que são princípios e a ter bom caráter, náo precisa de religiáo (ESP 08/05/2000). 
Essas pequenas narrativas vão aos poucos ajudando a construir, para o grande público, uma imaginação na qual as ideias morais possam ser vividas e pensadas como dissociadas das crenças e pertencimentos religiosos.

\section{c. Religióes nos Censos e casamento}

É interessante observar que as relaçôes entre religião e casamento também tenham atraído expressivo interesse da imprensa. Os números relativos às formas de nupcialidade da população brasileira aparecem pela primeira vez somente no Censo de 2010. A decisão de incluir o recenseamento de casais homoafetivos indica que esse tipo de uniáo começa a ser reconhecido oficialmente como imaginável. Nas narrativas da imprensa esse tema foi associado ao crescimento dos segmentos não religiosos. As manchetes chamam a atenção do público para a queda dos matrimônios, civis e religiosos, e para o crescimento de uniôes homoafetivas entre os não religiosos:

O Censo também aponta uma queda da taxa dos casados formalmente. Os casamentos informais são crescentes inclusive na população que se diz católica, embora a Igreja reprove esse tipo de união conjugal. O percentual de casados no civil e no religioso caiu de $49,4 \%$ para $42,9 \%$. Os sem religiâo são os que mais abriram mão da certidáo de casamento: $60 \%$ dos que têm união conjugal vivem em união consensual e apenas $18,4 \%$ são casados no civil e no religioso (FSP 17/1/2012)

No total de pessoas que declararam ter cônjuges do mesmo sexo, $47,4 \%$ se disseram católicas e 20,4\% sem religião (FSP 17/10/2012)

O Censo 2010 encontrou 60 mil casais homossexuais que dividem a mesma casa [...]. Desse total de uniôes, 53,8\% eram de mulheres. No total de pessoas que declararam ter cônjuges do mesmo sexo, 47,4\% se disseram católicas e 20,4\% sem religião. (ESP 17/10/2012). 
Ao apresentar esses números acompanhados de expressôes do tipo "inclusive os católicos"; "embora a Igreja reprove" -, as reportagens sublinham a dissonância entre os predicamentos da igreja católica quanto ao matrimônio e ao modo como a populaçáo que se diz católica vem se casando. Ao narrar os dados a partir de uma voz de observador externo e neutro que descreve uma evidência destituída de valor moral, as narrativas jornalísticas evidenciam (e reiteram) a disseminação da "uniâo consensual" como prática socialmente aceitável e incorporada à sensibilidade moral das famílias brasileiras, mesmo católicas. Ao mesmo tempo, as narrativas jornalísticas associam o crescimento das unióes consensuais ao abandono da religião:

O Censo também analisou o estado conjugal dos brasileiros em relação à religiáo. Entre os que se declaram católicos e evangélicos, a maioria optou pelo casamento civil e religioso: $37,5 \%$ e $26,5 \%$, respectivamente. A união consensual foi a principal escolha para quem se diz sem religião $(59,9 \%)(\mathrm{O}$ Globo, 2012).

Ao relacionar esse tema ao contingente crescente dos grupos náo religiosos, as narrativas jornalísticas ajudam a imaginar como possível, ainda que de outro ponto de vista, uma vida moral fora da religião. Na verdade, os dados censitários não apontam para uma conexáo direta entre uniáo consensual e falta de religiosidade: a pesquisa da FGV citada conclui apenas que "enquanto os homens abandonam as crenças as mulheres trocam de crenças" (Neri, 2011, p. 22). De qualquer modo, pode-se concluir que as questốes relativas ao casamento constituem uma arena politicamente sensível quando se trata de imaginar uma vida familiar não normatizada pela religiáo.

A análise desse conjunto de reportagens nos permitiu, pois, evidenciar como a reiterada imagem do declínio do catolicismo suscitou um conjunto particular de inquietaçóes e estimulou uma narrativa sobre seus impactos sociais, políticos e culturais. Nessas narrativas, a religiáo se torna um elemento central na compreensão das mudanças mais amplas do país, as quais envolvem 
projeçôes de futuro sobre as novas formas de convivialidade, de casamento e família e até mesmo no reequilíbrio das forças políticas.

\section{O CENSO E A ACADEMIA: ARTICULAÇÓES E TENSÓES ENTRE O IBGE E OS ESPECIALISTAS DA RELIGIÃO EM TORNO DA CLASSIFICAÇÃO DAS RELIGIÓES}

Muito do modo como os jornais comentaram a diversificação religiosa e não religiosa nos Censos se apoiou em comentários e resultados de pesquisa dos especialistas. Assim, é importante voltarmos agora nossa atenção para o modo como esses pesquisadores colaboraram com o IBGE na produção desses números. Veremos que o problema de como categorizar religióes tornou-se o eixo central do debate entre os estudiosos e também motivo de tensão entre as instituiçôes. Os pesquisadores estavam preocupados em capturar o fenômeno da diversificação religiosa e emergência de novos "cultos". Mas, como veremos a seguir, os modos de recensear enumeravam "igrejas".

A década de 1990 pode ser considerada um momento chave nas relações entre o Instituto Brasileiro de Geografia e Estatística (IBGE) e o campo de estudos da religião, sobretudo no que concerne às Ciências Sociais. Segundo Decol (2014, p. 1053), o processo de redemocratização estimulou a aproximação do IBGE com os núcleos de demografia já então bem estruturados nas principais universidades do país. Por sugestão dos especialistas, o levantamento de 1991 ampliou ao máximo a lista das categorias religiosas tabuladas na listagem final ${ }^{10}$. Para dar conta da classificação dos muitos novos nomes de religióes que não constavam nos registros pré-codificados, o Instituto buscou por colaboraçóes de sociólogos, antropólogos e outros profissionais das Ciências Sociais (Santos, 2014, p. 21-22).

${ }^{10} \mathrm{Na}$ maior parte dos levantamentos a pergunta sobre religião era aberta figurando nas tabulaçóes finais apenas as categorias religiosas mais recorrentes. No levantamento de 1980 foram enumeradas apenas nove categorias. (Decol, 2014, p. 1051-1052).

Debates do NER, Porto Alegre, ano 20, N. 38, P. 339-373, Ago./Dez. 2020 
Em 1997 o IBGE propôs parceria com o Instituto de Estudos da Religião (ISER) solicitando-lhe que fizesse um trabalho de tabulação e classificação dos novos grupos religiosos nomeados pelos declarantes de 1991 . Por nunca terem sido mencionados antes eles não cabiam nos descritores já estabelecidos. Segundo Camurça (2014, p. 10), a equipe do ISER, sob sua coordenação, viu-se diante de uma enorme diversidade de novos "nomes", sobretudo no campo evangélico, mas também, das religiosidades populares e afro-brasileiras. A grande variedade das respostas oferecidas naquele ano tornara extremamente complexo o processo de categorização gerando sobreposições e a multiplicação exponencial de "cultos"11. Para sanar esse problema a equipe propôs, para o Censo de 2000, o desdobramento de vários descritores já existentes.

A colaboração entre pesquisadores e os responsáveis pelo Censo logo se defrontou com um impasse de difícil solução. O objetivo oficial do Censo é o de enumerar os membros de cada grupo religioso existente. Dito assim, parece tarefa simples, sobretudo se apoiada por um grupo de especialistas em estudos da religião. Mas, na verdade, a catalogação daquilo que poderia ser considerado "uma religião existente" gerou alguma tensão entre as equipes e um intenso debate sobre a melhor maneira de realizá-la. A natureza desse debate nos interessa particularmente, uma vez que ele ilumina uma dificuldade inerente (e por enquanto incontornável) a esse esforço de categorização das religióes: a enorme distância entre o que o Censo deseja saber e o que as pessoas respondem quando perguntadas. Veremos adiante como essa dificuldade acaba por definir os termos a partir dos quais se concebe o pluralismo religioso no trabalho acadêmico. Para restituir esse debate e conferir-lhe um fio condutor, digamos, resumidamente, que no cerne da disputa estava o próprio processo de nomeação e classificação. Por que, como e para quem classificar religióes?

${ }^{11}$ No Censo 2000 o processo se repetiu: foram coletadas mais de 35 mil respostas diferentes, as quais foram posteriormente classificados em 144 categorias (Camurça, 2006, p. 37). 
Comecemos com a única questão proposta pelo Censo: "qual é a sua religião ou culto?”. Ela é opcional e cada indivíduo particular deve respondê-la "com suas próprias palavras não importando se frequenta uma igreja ou se observa todos os seus preceitos" (Decol, 2014, p. 1051). Embora aparentemente objetiva, essa formulação silencia alguns supostos sobre o que se quer enumerar. Clara Mafra (2004) comenta que não havia como saber de que forma o entrevistado entendia o que lhe fora perguntado. Pelos milhares de nomes diferentes recebidos, é de se supor que o sentido da pergunta era dúbio para o entrevistado.

O que o Censo desejava saber com essa pergunta? Embora ela indague sobre a religiáo ou culto do declarante, a questão não explicitava que o respondente deveria, obrigatoriamente, nomear uma igreja ou denominação (Gracino Jr., 2012, p. 1157). Instruçóes claras no manual do recenseador orientavam para que não se registrassem expressóes genéricas do tipo "Católica”, "Protestante”, "Espírita”, "Crente”, "Evangélica” (IBGE 2009), sem a nomeação de uma igreja específica (Altmann, 2012, p. 1128). Ora, tendo em vista que o entrevistador era orientado a não reformular a pergunta e apenas aceitar uma resposta como válida, pode-se imaginar o forte ruído que permeou essa comunicação nos levantamentos. $\mathrm{O}$ que se pode dizer, então, a respeito desse procedimento estatístico de inscrever nomeaçóes declaradas (ou imaginadas) de milhares de religiōes e cultos?

Salta aos olhos, em primeiro lugar, que a pergunta está informada por uma sociologia religiosa dos anos 1950 e 1960 que, inspirada no formato eclesial da igreja católica, produz uma tipologia que privilegia o critério da filiação institucional. Como mencionamos acima, a questão do Censo não quer saber nem das crenças dos respondentes, nem de suas formas de frequência aos cultos. Como interpretar, entáo, as referências a partir das quais os respondentes declaram sua religiáo: a partir de sua identidade e crenças, como sugere Giumbelli? (2013, p. 59); a partir de sua frequência atual (Novaes 2013, p. 112)?; a partir da legitimidade social de sua autoapresentação?

Quando os pesquisadores foram convidados a colaborar na classificação da diversidade religiosa, as Ciências Sociais já haviam acumulado 
pelo menos uma década de estudos qualitativos sobre as diferentes formas de conceber o pertencimento religioso. Já se sabia, por exemplo, que na lógica sacramental da igreja católica, é considerado católico todo aquele que recebeu o batismo e náo foi excomungado, ainda que náo frequentasse a igreja (Oliveira 2012, p.102). No protestantismo, ao contrário, frequência e assiduidade teriam sido, até muito recentemente, critérios de declaração de filiação (Novaes 2013, p. 113). Muitos estudos das últimas três décadas também já haviam começado a observar uma profunda transformaçáo no comportamento das pessoas com relação às instituiçóes religiosas, fenômeno este que Danièle Hervieu-Léger (2008) chamou de "desfiliação religiosa".

À luz dessa experiência, a incrível quantidade de novas nomeaçốes de cultos tornava ainda mais premente para os pesquisadores a necessidade de compreender melhor o modo como as pessoas se relacionam com as organizaçôes religiosas mencionadas. Esse desconhecimento tornava mais espinhosa a tarefa solicitada - a de classificar religióes. Ainda assim, uma vertente de argumentos presumia que a pergunta aberta permitiria capturar a emergência de novas religióes (Mariz, 2013, p. 56) e tornar as categorias mais afeitas às novas configuraçôes religiosas (Mafra 2004). Estava claro, no entanto, que alocar as respostas em uma grade (ainda que ampliada) de instituiçóes religiosas, sem levar em conta as mais diferentes formas de filiação, constituía uma contradição em seus próprios termos.

À publicaçáo dos números logo seguiu-se um intenso debate metodológico sobre a melhor maneira de interpretá-los. Novaes (2013, p. 114) observa que o modo como as pessoas se movem entre as instituiçóes religiosas, no seu interior e para fora delas, exigiria uma revisão do procedimento de mapear religióes a partir da ideia clássica de pertencimento. Essa exigência teria se tornado ainda mais urgente com o Censo de 2010, que registrou um impressionante número de "evangélicos não determinados" (Mariz, 2013). Assim, por mais que os pesquisadores estivessem cientes dessa radical diferença de abordagem entre o que o Censo pretendia enumerar e o que as pesquisas socioantropológicas já sabiam, a tarefa solicitada - agrupar respostas em categorias correspondentes a instituiçôes religiosas - reiterava, apesar 
dos pesquisadores, uma visão topográfica da diversidade religiosa que (re) produzia novas fronteiras institucionais fechadas em seus territórios próprios (Steil, 2013, p. 29). Essa talvez tenha sido uma das principais razóes das tensóes que marcaram a parceria entre o ISER e o IBGE ${ }^{12}$.

Por mais que os pesquisadores se denodassem em multiplicar as nomeações, a noção de filiação implícita na operação acabava por reiterar, paradoxalmente, a sinonímia religiáo/igreja que o próprio processo social estava se encarregando de distinguir e as pesquisas qualitativas buscando superar ${ }^{13}$. Depreende-se, portanto, que a crítica dos especialistas da religião ao Censo não é apenas técnica e institucional, mas tem também uma dimensão epistemológica. No entanto, como veremos a seguir, apesar dos esforços críticos dos especialistas, os efeitos da reificação estatística acabam por transferir-se, em parte, para os estudos acadêmicos quando, tomando como referência os números dos Censos, os pesquisadores colocam na sua agenda um tema novo: o pluralismo religioso.

12 Além dessa diferença de abordagens, Mafra (2004) e Camurça (2014) mencionam tensões relativas ao comportamento pouco colaborativo dos pesquisadores e técnicos do IBGE na formulação dos descritores a serem utilizados na classificação das declaraçôes do Censo 2000.

13 Menezes (2014, p. 63-64) sugere que as categorias do Censo produzem um efeito de reificação, apresentando identidades construídas enquanto fenômenos reais. Na mesma direção, Camurça (2014) defende que apenas os dados quantitativos não seriam suficientes para uma análise refinada do panorama religioso brasileiro: sincretismos, porosidades, múltiplas pertenças e trânsitos religiosos teriam mais importância do que o registro pontual da pertença a uma instituição religiosa. Teixeira (2013a, p. 77), por sua vez, reconhece que os dados do Censo captam apenas um momento instantâneo "que deixa escapar os 'movimentos finos' que envolvem a presença e circulação das religióes no campo religioso".

Debates do NER, Porto Alegre, ano 20, N. 38, P. 339-373, Ago./Dez. 2020 


\section{A LITERATURA ACADÊMICA E AS DINÂMICAS RELIGIOSAS PROBLEMATIZADAS A PARTIR DOS DADOS DO CENSO}

Segundo Decol (1999), até muito recentemente, poucos analistas no campo de estudos da religiáo haviam se debruçado sobre informaçóes estatísticas ${ }^{14}$. Os empreendimentos sociográficos e censitários foram iniciativas lideradas, inicialmente, por instituiçôes ligadas à igreja católica (CERIS e IBRADES) (Mariz e Mafra, 2007). Esses levantamentos tinham como objetivo oferecer subsídios para a ação pastoral católica (Sanchis, 2007) e para a ação social evangélica.

Na década de 1980, por influência da atuação do ISER, começa a ganhar força, pelo menos no Rio de Janeiro, a convergência entre os estudiosos católicos e evangélicos. Dessa associação resultaram os estudos sobre as mudanças na catolicidade coordenados por Pierre Sanchis (1992) e sobre a mudança no perfil dos evangélicos sob a liderança de Rubem Cesar Fernandes. Em coletânea de 1998, Novo Nascimento, procurou-se incorporar, a partir de uma metodologia inovadora e de novos critérios classificatórios a nova pluralidade das denominaçóes evangélicas.

Além dos efeitos reificadores da categorização e da nomeação, um dos mais importantes resultados desses levantamentos censitários recentes sobre os estudos acadêmicos foi introduzir uma leitura transversal das religióes. A operação cognitiva implicada na ação de quantificar adeptos coloca em relaçáo grupos religiosos qualitativamente distintos que se tornam comparáveis. A ação de comparar, inerente ao esforço estatístico, suscita "naturalmente"

${ }^{14}$ Podemos citar como exceção os trabalhos de Cândido Procópio de Camargo nos anos 1970 que usaram dados censitários de 1940, 1950 e 1960, além de outras estatísticas governamentais. Antonio Flávio Pierucci e Reginaldo Prandi (1996) usaram dados estatísticos do Datafolha para escrever o livro A realidade social das religióes. Em 1992 o ISER fundou um núcleo de pesquisas que combinava trabalho de campo com técnicas quantitativas. Rubem César Fernandes (1998), a partir dos dados do Censo Institucional Evangélico de 1991 produzido pelo ISER, organizou uma pesquisa que redundou na obra coletiva Novo Nascimento: os Evangélicos em casa, na igreja e na política.

Debates do NER, Porto Alegre, ano 20, N. 38, P. 339-373, Ago./Dez. 2020 
perguntas relativas às razóes do crescimento e declínio demográfico de determinados grupos e, por via de consequência, sobre o impacto dessas oscilaçôes na estrutura das relaçóes que as religiōes mantêm entre si. No conjunto de mais de 63 títulos analisados para este artigo pode-se perceber que a noção de campo religioso foi o modo sobressalente de tratar analiticamente a diversidade tornada visível pela abordagem demográfica das religióes. A noção de campo religioso naturalizou-se como uma nova forma de enquadrar os temas, já repertoriados na década anterior a partir da visibilidade, que adquiriram na gramática censitária, a saber: a diversificação religiosa; a desfiliação e circulação dos indivíduos entre as fronteiras organizacionais e o declínio da maioria católica. Vejamos então, com mais detalhes, como esse conceito foi operacionalizado para fazer frente a esses temas.

\section{A. CAMPO RELIGIOSO E Diversidade RELIGIOSA}

Nesse movimento de integração dos dados censitários às pesquisas acadêmicas, nota-se que o conceito do sincretismo, de longa tradição nos estudos afro-brasileiros, começa a perder centralidade, dando lugar à noção de campo religioso que enfatiza a pluralidade das religiôes e as dinâmicas que mantém entre si. Inspirada nos trabalhos de Pierre Bourdieu (1974) que analisam a concorrência entre instituiçóes produtoras de capital religioso, essa noçáo rapidamente se naturaliza no vocabulário das Ciências Humanas para descrever uma diversidade tornada cada vez mais evidente pelos números censitários. É difícil recuperar a genealogia desse conceito, mas pode-se afirmar que sua plausibilidade é, em grande parte, tributária da imagem demográfica oferecida pelos Censos. A categoria pode ser rastreada já na tese de doutorado de Carlos Brandão (1980; 1985) que, atenta aos números e proporçôes estatísticas, trata a "religião popular" (catolicismo/ Pentecostalismo/Macumba) como parte de um campo religioso atravessado, como propôs Bourdieu, pela oposição entre dominantes e dominados, eruditos e populares. Mas não se pode deixar de mencionar também o trabalho pioneiro de Cândido Procópio Camargo "Católicos, Protestantes, 
Espíritas" (1973), uma das primeiras obras a utilizar os dados do Censo para elaborar um conjunto de teses sobre as mudanças religiosas a partir da década de 1950 (Godoy e Carvalho, 2017). Inspirado em uma sociologia da mudança de matriz weberiana, uma das preocupaçóes centrais de Camargo foi a de pensar os impactos do processo de secularização em curso sobre as condutas religiosas (Montero, 1999). Embora não tenha utilizado o conceito de campo religioso, mas sim de gradiente ou continuum mediúnico ${ }^{15}$, o trabalho de Camargo já apresentava o germe de uma interpretaçáo espacial que se tornaria recorrente na literatura acadêmica sobre o campo religioso nas décadas seguintes.

Ao comentar as mudanças observáveis no Censo de 1991, Pierre Sanchis (1997, p. 28) afirmou que "a passagem do quase singular ('a religiáo') para um claro e crescente plural ('as religiôes') sem dúvida constitui a transformação mais significativa ocorrida no campo religioso do Brasil". Carlos Steil (2001) reitera a interpretaçáo da pluralidade religiosa como um fenômeno que teria origem na ruptura do monopólio de uma religiáo oficial, seja pelo avanço da secularização, seja pela diversificação do campo religioso.

Para além desses estudos isolados, a pluralidade religiosa, formulada em termos do declínio do monopólio católico e da diversificaçáo da filiação religiosa e dos sem religiáo, foi estatisticamente representada por alguns intérpretes dos dados censitários, tal como o influente Atlas da Filiação Religiosa e Indicadores Sociais (Jacob et al., 2003), a partir de uma dimensão topográfica. Segundo seu autor, esse trabalho constituiu uma tentativa de representar a filiaçáo religiosa brasileira por meio da elaboraçáo de mapas microrregionais. Marcelo Neri, em seu trabalho o Novo Mapa das Religióes (2011) também procura mapear a demografia das filiaçôes religiosas em

${ }^{15}$ Ao contrário de "campo religioso" que tem sido utilizado como referência à pluralidade empírica de grupos religiosos no espaço social, o conceito de "continnum" se apresenta como uma ferramenta analítica para pensar a mudança religiosa entre o polo tradicional e o moderno. Nesse sentido a categoria se situa no meio do caminho entre a noção de sincretismo e a de campo.

Debates do NER, Porto Alegre, ano 20, N. 38, P. 339-373, Ago./Dez. 2020 
termos territoriais. Essa visão panorâmica e sócio demográfica da diversidade contribuiu, de certo modo, para cristalizar uma imagem cartográfica da diversidade implicada na noção de campo religioso que perdura até hoje.

\section{B. CAMPo RELIGIOSO E CirCULAÇÃo}

Em seus comentários sobre a produção dos números no Censo de 2010, Clara Mafra (2013a) critica o reducionismo inerente a esse modelo topográfico, sugerindo que, na análise do campo das religióes, se substitua a metáfora do mapa pela do holograma. A seu ver, o holograma seria capaz de representar as unidades religiosas de maneira menos unidimensional e estática. Independentemente da eficácia dessa substituição, a ideia de holograma não nos parece suficiente para romper com a imagem topográfica da pluralidade religiosa se, ao mesmo tempo, não se abandona a noção de campo religioso imaginado como expressão das alternativas religiosas. Ainda assim, o comentário de Mafra sobre o modelo holográfico suscitou um interessante debate em torno de algumas questóes inerentes ao problema da pluralidade religiosa que a própria noção de campo religioso procurou enfrentar, entre elas o da circulação entre fronteiras religiosas.

Pedro de Oliveira (2013) retoma o problema da circulação entre as religiôes e distingue a noção de "conversão", que consiste em uma ruptura com um sistema religioso e adesáo a um outro, da ideia de "trânsito" que significaria "mudar de religião para não alterar o modo de vida" (2013, p. 101). No ambiente pluralista atual essa modalidade seria, segundo ele, mais frequente. Na mesma direção, Amaral (2013) assinala uma tendência crescente no Brasil de uma "cultura religiosa errante", cujo foco seriam as práticas, ao invés das definiçóes ou inserçôes religiosas. Procurando escapar da rigidez atrelada à noção de identidade religiosa, a ideia de uma cultura errante sugeriria, não um único lugar institucional ou territorial, mas múltiplos ambientes culturais em interação (Amaral 2013, p. 294).

Vemos, portanto, que o aporte da noção de campo religioso para os estudos da religiáo, situa-se, em parte, na sua capacidade de representar 
sinteticamente uma imagem das diferentes religióes colocadas em relação em um mesmo espaço social por meio da circulação das pessoas. Sua eficácia analítica se expressa no abandono de conceitos como o de "conversão" em prol de fórmulas do tipo "cultura religiosa errante". Nesse sentido, autores como Almeida (2010) e Luiz (2013) diagnosticam uma maior fluidez das fronteiras institucionais produzida por essa circulação de pessoas, práticas e bens simbólicos que, muitas vezes, redundam na invenção de uma religiosidade pessoal destituída de pertencimentos institucionais. Denominada de "trânsito religioso" essa circulação também seria responsável pelo crescimento da categoria dos "sem religiáo" capturada pelos Censos recentes (Rodrigues 2012).

A abordagem em termos de campo religioso, ao privilegiar a circulação, enfraquece, pois, o rendimento das análises que tratam as religióes na chave das identidades/pertencimentos, embora esta percepçáo ainda permeie fortemente o imaginário social midiático, como vimos no início. Ao suscitar um olhar que coloca as passagens entre religióes no centro da análise, a noção de campo religioso acomodou um enquadramento da pluralidade associada ao tema da desinstitucionalização ou destradicionalização religiosa (Pierucci 2004). Na leitura de Oliveira (2013), a expressão da "religião cristã em fluxo" proposta por Mafra (2013a, p. 22), deve ser compreendida, na verdade, como "cultura católica em dissolução" (Oliveira 2013, p. 105). Para Pierucci (2006, p. 24), esse rompimento com o passado do Brasil como "nação católica" corresponderia a um duplo movimento de destradicionalização da religião católica e des-etnização das religiôes afro. Sanchis (2012), por sua vez, usaria a imagem de uma "religiosidade alargada" para tratar o tema do avanço da diversidade religiosa. Em trabalho posterior, o autor (2013, p. 13) destaca o crescente processo de desinstitucionalização das religióes como uma importante característica do campo religioso brasileiro, na qual as "estruturas sólidas que fundavam, enquadravam, regulavam o universo das experiências religiosas, conferindo-lhes distinção, identidade e conteúdo, não o fazem com o mesmo rigor" ou "com a mesma abrangência”. 
Seguindo os passos de Sanchis, Teixeira (2013b, p. 22) reafirma que o campo religioso brasileiro estaria deixando de ser regido por estruturas sólidas e reguladoras, tornando-se cada vez mais fluido e pontuado por relaçóes menos rígidas e totalizantes entre fiéis e instituiçōes religiosas. Apesar de as noçóes de destradicionalização e desinstitucionalização - assim como as de mobilidade e circulação - destacarem a fluidez, os dinamismos e as rupturas com os vínculos identitários e modos de pertencimentos historicamente constituídos no Brasil, parece-nos que a recorrência ao uso acrítico e naturalizado da ideia de um campo religioso como um espaço onde os atores se movem entre as religióes ou como alternativas que se oferecem para sua escolha, acaba por reificar as fronteiras institucionais e restringir a análise aos limites das relaçóes e práticas inter e intrarreligiosas. Ao mesmo tempo, como veremos a seguir, o uso quase naturalizado da noçáo de campo circunscreve o debate do pluralismo à diversidade das religiôes e às relaçôes que elas mantêm entre si.

\section{Campo Religioso e pluralismo}

Para Clara Mafra os números dos Censos estariam demonstrando que o catolicismo passou de "uma religiáo dos brasileiros" para uma "religiáo de maioria" (Mafra, 2012). A afirmação nos parece, ao mesmo tempo, intrigante e provocadora. Afinal, uma "religião dos brasileiros" também é majoritária. A frase náo vem acompanhada de maiores explicitaçóes, mas sugere um deslocamento no catolicismo do domínio da cultura para o da política. Essa passagem resultaria do simples declínio numérico da populaçáo católica? A autora afirma apenas que os números envolvem disputas entre maiorias e minorias religiosas e essas disputas se fariam, em parte, por meio do uso político dos dados censitários (Mafra, 2013b). Embora possamos concordar que os números se prestam a narrativas político-ideológicas, como vimos no início deste texto, não está muito claro como a noçấo de maioria está sendo utilizada pela autora, se no seu sentido meramente demográfico ou como conceito político. De qualquer modo, o tema suscitou um interessante 
debate sobre o rendimento dessa categoria para interpretar a pluralidade religiosa brasileira.

Alguns anos antes, ao comentar os dados do Censo de 2000, Emerson Giumbelli (2006, p. 229-235) observara que "jamais o vocabulário derivado das noçóes de maioria e minoria se tornou dominante ou mesmo recorrente, (nas Ciências Sociais) para descrever nossa pluralidade religiosa”. Isto porque, segundo ele, as minorias estatísticas, tais com os espíritas, afro-brasileiros ou as variaçôes contemporâneas do "neo-esterismo", jamais se comportaram como minorias religiosas. Fronteiras identitárias fortes e pouco permeáveis associadas à marginalidade política e cultural desses grupos seriam, segundo o autor, algumas das condiçōes mínimas necessárias à constituição de minorias religiosas. Acrescentaríamos a essas condiçóes a que aventamos no início deste artigo ao citarmos Kraut (1999): a ausência de redes de coalizóes em torno de interesses pontuais.

O conjunto de estudos aqui mencionados apontam, com efeito, na direçáo contrária: grande mobilidade interinstitucional, fragilidades identitárias favorecidas pela destradicionalização, fragmentação de formatos, fraca representação política, e capacidade de estabelecer alianças. Mesmo as tentaçôes minoritárias de algumas correntes evangélicas fundadas em sua ênfase identitária, tais como a exigência de exclusivismo e disputas contra a maioria católica, se enfraqueceriam diante de sua pulverização institucional e intensa circulação dos frequentadores.

Talvez por essas características o modelo teórico de campo religioso e náo o de pluralismo tenha se tornado a forma consagrada nos estudos acadêmicos que se seguiram às evidências censitárias sobre a configuração da diversidade religiosa. Na literatura sobre o pluralismo, a diversidade é tratada como um fato político e jurídico. Trata-se, de um modo geral, de responder às tensóes provocadas pela diversificação moral e examinar as experiências legais das minorias religiosas (Durham e Thayer, 2019). A descriçấo da diversidade religiosa em termos de campo religioso enfatiza, ao contrário, a comparaçáo das religióes entre si sem colocar na equação o problema da diversidade das 
religiôes quando elas se posicionam na esfera pública. Giumbelli, um dos raros autores a sugerir que os números dos Censos poderiam estar estimulando o surgimento de uma retórica de minorias, observa que eles começaram a servir de instrumento para orientar, por exemplo, a distribuição de cargos públicos nas escolas.

Com efeito, o problema ideológico e normativo do pluralismo se póe na medida em que as maiorias/minorias religiosas, descritas em termos demográficos, começam a ser pensadas em termos de seus direitos de cidadania, equidade e liberdade. Curiosamente, a mídia antecipou essa preocupaçáo quando, por um lado, associou maiorias religiosas e políticas e, de outro, dedicou longos comentários às relaçôes entre religião e tipos de união conjugal. Nos estudos acadêmicos, ao contrário, o declínio do catolicismo evidenciado nos Censos mobilizou uma reflexão a respeito de seu impacto sobre o campo das relaçóes entre religióes deixando praticamente em silêncio o fato tão destacado no noticiário jornalístico de seus efeitos sobre a conjugalidade e a convivialidade.

\section{CONSIDERAÇÕES FINAIS}

Os dados censitários sobre as mudanças no panorama religioso brasileiro nas últimas décadas capturaram a atenção de setores da mídia e da academia. $\mathrm{O}$ interesse pelo tema pôde ser medido pelo expressivo número de reportagens veiculadas no período e a grande quantidade de trabalhos acadêmicos que se ocuparam em refletir sobre esses dados, sobretudo a partir dos anos 2000. Contudo, ainda que esses setores estejam fortemente interligados em função da circulação dos atores e das informaçôes e interpretaçôes, jornalistas e pesquisadores escrevem para audiências bastante diferentes: enquanto os primeiros se dirigem para uma opiniáo pública imaginada, os segundos o fazem para seus pares. Este artigo nasce justamente estimulado por essa distinção. Interessava-nos compreender de que forma e porque o declínio do catolicismo interessa como questão de pesquisa e como notícia. 
Vimos que as leituras desse declínio foram processadas nessas duas áreas de modos bem diferentes. Enquanto as reportagens jornalísticas suscitaram a imagem de uma nacionalidade não católica ou mesmo não religiosa, a reflexão acadêmica ocupou-se com as questôes relativas às formas de categorizar a diversidade religiosa. A imagem das distinções institucionais das religiōes, que os Censos fortaleciam por meio de suas expressões estatísticas, foi tratada como uma evidência pela imprensa. Já para a reflexão acadêmica, tornou-se o problema central a enfrentar. Tratava-se de nuançar, desfazer as categorias, multiplicá-las, ler o que os números obscureciam.

Essas diferenças de audiências talvez expliquem porquê os relatos jornalísticos associaram intuitivamente o declínio do catolicismo à uma dimensão política. Tratou-se de antecipar a natureza e direção das novas maiorias religiosas. Vinculou-se a perda de influência católica às mudanças no fundamento moral do casamento. Já a reflexão acadêmica foi profundamente impactada pela visão transversal e concorrente que a representaçáo estatística da variedade religiosa instituiu. $\mathrm{O}$ conceito de campo religioso emerge como um enquadramento capaz de dar conta, ao mesmo tempo, das mudanças institucionais e do fenômeno religioso observando as religióes da perspectiva das relaçóes que mantêm entre si.

Curiosamente, Bourdieu (1987, p. 121-122) propõe a noção de "campo religioso" para falar da "dissolução do religioso" e não de sua pluralização, tema tão amplamente reiterado nos estudos aqui mencionados (Mafra, 2013a; Teixeira, 2014). Em sua crítica ao conceito weberiano de "esfera", Bourdieu considera que ele se tornou demasiadamente estreito para descrever o espaço no qual diferentes agentes (religiosos e não religiosos) disputam a definição das competências e do controle da vida privada. Nesse sentido, o conceito, tal como foi utilizado pelos estudos inspirados nos Censos, reduziu o campo religioso ao campo das religióes e suas fronteiras. Ao limitar-se a descrever o declínio, o crescimento demográfico de uma ou outra religião, a multiplicação de cultos e das formas de pertencimento religioso, esses estudos não levaram adiante o programa intelectual inerente ao conceito bourdieusiano de campo religioso, que é, não apenas o de flexibilizar as fronteiras entre as 
religiôes, mas sobretudo, o de desagregar as fronteiras entre os fenômenos tidos como religiosos e os náo religiosos (Montero 2016).

Um dos efeitos desse uso topográfico da noção de campo pode ser percebido no modo como a literatura incorpora a categoria dos "sem religião" ao tema da diversidade e suas dinâmicas. Assis (2017, 40-41), por exemplo, insere os sem religiáo no âmbito do aumento da "pluralidade de alternativas religiosas". Camurça (2017), por sua vez, busca pensar os "sem religiáo" na esfera das mudanças nos comportamentos com relaçáo à própria religiáo. Nessas abordagens, a expansão do número de pessoas "sem religião" é, pois, interpretada como um desdobramento das dinâmicas próprias ao campo religioso.

Apesar do esforço dispendido em complexificar as definiçóes de fronteiras religiosas reificadas pelos tratamentos estatísticos, as análises acadêmicas acabaram por reduzir o pluralismo à diversidade religiosa confinada aos limites e às dinâmicas internas ao próprio campo religioso. $\mathrm{O}$ modo como as lideranças religiosas passaram a ocupar a esfera pública midiática, parlamentar, e mais recentemente, executiva, exigirá, no entanto, um deslocamento no investimento de nossa reflexáo, de modo a expandir o tema da pluralidade religiosa em direçáo ao problema do pluralismo entendido, aqui, como fenômeno político e jurídico que se estende para além das fronteiras daquilo que foi pensado como religioso.

\section{REFERÊNCIAS}

ALMEIDA, Ronaldo de. Religião em Transição. In: MARTINS, Carlos B. (coord.) e DUARTE, Luiz F. D. (org.). Horizontes das Ciências Sociais. Antropologia, São Paulo, Anpocs, 2010.

ALTMANN, Walter. Censo IBGE 2010 e religiōes. Horizonte, Belo Horizonte, vol. 10, n. 28, p. 1122-1129, 2012. 
AMARAL, Leila. Cultura religiosa errante: O que o Censo 2010 pode nos dizer além dados. In: TEIXEIRA, Faustino; MENEZES, Renata (org.). Religióes em movimento: o Censo de 2010. Petrópolis: Vozes, p. 295-310, 2013. ASSIS, Thais Silva de. Religiosos sem religião: Nuances sociais de uma tendência. Áskesis, v.6, n.1, p. 40-51, 2017.

BOURDIEU, Pierre. Gênese e estrutura do campo religioso. In: BOURDIEU, Pierre. A Economia das Trocas Simbólicas. São Paulo: Perspectiva, p. 27-78, 1974.

BOURDIEU, Pierre. A dissolução do religioso. In: BOURDIEU, Pierre. Coisas Ditas. São Paulo: Brasiliense, p. 119-125, 1987.

BRANDĀO, Carlos Rodrigues. Os Deuses do Povo, Um estudo sobre a religiāo popular. São Paulo: Brasiliense, 1980.

BRANDÃO, Carlos Rodrigues. Memória do Sagrado: estudos de religiäo e ritual. São Paulo: Paulinas, 1985.

CAMARGO, Cândido Procópio. Católicos, protestantes, espiritas. Petrópolis: Vozes, 1973.

CAMURÇA, Marcelo. A realidade das religióes no Brasil. In: TEIXEIRA, Faustino; MENEZES, Renata. As religiōes no Brasil: continuidades e rupturas. Rio de Janeiro: Vozes, p. 35-46, 2006.

CAMURÇA, Marcelo. A religião e o Censo: enfoques metodológicos. Uma reflexão a partir das consultorias do ISER ao IBGE sobre o dado religioso nos censos. Religiōes em conexão: números, direitos, pessoas - Comunicaçôes do ISER, Rio de Janeiro, n. 69, p. 08-17, 2014.

CAMURÇA, Marcelo. Os "Sem Religiāo" no Brasil: Juventude, Periferia, Indiferentismo Religioso e Trânsito entre Religiōes Institucionalizadas. Estudos de Religiäo, v. 31, n. 3, p. 55-70, 2017.

DECOL, René Daniel. Imigraçôes urbanas para o Brasil: o caso dos judeus. Tese de doutorado em Sociologia. Universidade de Campinas, 1999. 
DECOL, René Daniel. Brasil e as fontes de dados demográficos sobre religião. Horizonte, Belo Horizonte, v. 12, n. 36, p. 1051-1054, 2014.

DURHAM Jr. W. Cole; DONLU, D. Thayer (org.). Religion, Pluralism, and Reconciling Difference. London/NY: Routledge, 2019.

FERNANDES, Rubens César et al. Novo Nascimento: os Evangélicos em casa, na igreja e na política. Rio de Janeiro: Mauad, 1998.

GIUMBELLI, Emerson. Minorias religiosas. In: TEIXEIRA, F.; MENEZES, R. (org.). As Religióes no Brasil: continuidades e rupturas. Petrópolis: Vozes, p. 229-245, 2006.

GIUMBELLI, Emerson. Em busca da narrativa da diversidade. Debates do NER, Porto Alegre, ano 14, n. 24, p. 59-75, 2013.

GODOY, João Miguel Teixeira; CARVALHO, Maria Gabriela. Cândido Procópio Ferreira de Camargo: a sociologia da religiáo no Brasil. Reflexus, Vitória, v. 11, n.18, p. 471-498, 2017.

GRACINO JR, Paulo. A visão aérea e a do nadador: reflexões sobre catolicismo e pentecostalismo no censo de 2010. Horizonte, Belo Horizonte, vol. 10, n. 28, p. 1154-1183, 2012.

HERVIEU-LÉGER, Danièle. O Peregrino e o Convertido: A religião em movimento. 2a. edição, Paris: Flammarion; Petrópolis: Vozes, 2008.

JACOB, César Romero et al. Atlas da filiação religiosa e indicadores sociais no Brasil. Rio de Janeiro: Ed. PUC-Rio; São Paulo: Loyola, 2003.

KRAUT, Stephan. O Princípio da Maioria. Cadernos da Escola do Legislativo, Belo Horizonte, v. 5, n. 9, p. 89-140, 1999.

LUIZ, Ronaldo Robson. A religiosidade dos sem religião. Ciências Sociais e Religiāo, ano 15, n. 19, p. 73-88, 2013.

MAFRA, Clara. Censo da Religião: um instrumento descartável ou reciclável?. Religião e Sociedade, Rio de Janeiro, v. 24, n.2, p. 152-159, 2004. 
MAFRA, Clara. O percurso que faz o gênero. Religiäo e Sociedade, Rio de Janeiro, v. 32, n. 2, p. 124-148, 2012.

MAFRA, Clara. Números e narrativas. Debates do NER, Porto Alegre, ano 14, n. 24, p. 13-25, jul-dez, 2013 a.

MAFRA, Clara. O que os homens e as mulheres podem fazer com os números que fazem coisas. In: TEIXEIRA, Faustino; MENEZES, Renata. Religióes em movimento: o Censo de 2010. Petrópolis: Vozes, p. 37-48, $2013 \mathrm{~b}$. MARIZ, Cecília e MAFRA, Clara. Estudos sobre religião na Pós-Graduação em Ciências Sociais. Debates do NER, Porto Alegre, ano 8, n. 11, jan-jun, p 21-48, 2007.

MARIZ, Cecília. O que precisamos saber sobre o censo para poder falar sobre seus resultados? um desafio para novos projetos de pesquisa. Debates do NER, Porto Alegre ano 14, n. 24, p. 39-58, jul./dez, 2013.

MENEZES, Renata de Castro. Religióes, números e disputas sociais. Religiôes em conexão: números, direitos, pessoas - Comunicaçôes do ISER, Rio de Janeiro, n. 69, p. 60-71, 2014.

MIGUEL, Nadya Maria Deps. O perfil do brasileiro construido pelo IBGE. Tese de doutorado em Memória Social. Universidade Federal do Rio de Janeiro - UNIRIO, 2012.

MONTERO, Paula. Religióes e dilemas da sociedade brasileira. In: MICELI, Sérgio. O que ler na Ciência Social brasileira. Sáo Paulo: Sumaré; Brasília: ANPOCS/CAPES, p. 327-367, 1999.

MONTERO, Paula. Religiôes Públicas ou religiōes na Esfera Pública? Para uma crítica ao conceito de campo religioso de Pierre Bourdieu, Religiáo e Sociedade, junho vol. 31. n 1, p.128-150, 2016.

NERI, Marcelo Côrtes; MELO, Luísa Carvalhaes Coutinho de. Novo Mapa das Religiôes. Horizonte, Belo Horizonte, vol. 9, n. 23, p.637-673, 2011. 
NOVAES, Regina. Sobre números e narrativas estabelecidas: alguns comentários ao artigo de Clara Mafra. Debates do NER, Porto Alegre, ano 14, n. 24, p. 109-117, 2013.

OLIVEIRA, Pedro Ribeiro de. Pertença/desafeição religiosa: recuperando um antigo conceito para entender o catolicismo hoje. Horizonte, v.10, n. 2, p. 1230-1254, 2012.

OLIVEIRA, Pedro Ribeiro de. As religióes no censo de 2000: uma reflexão. Debates do NER, Porto Alegre, ano 14, n. 24, p. 99-107, 2013.

PIERUCCI, Antônio Flávio e PRANDI, Reginaldo. A realidade social das religióes no Brasil: religiāo, sociedade e politica. São Paulo: Hucitec, 1996.

PIERUCCI, Antonio Flávio. Bye bye, Brasil: O declínio das religiôes tradicionais no Censo 2000. Estudos Avançados, São Paulo, v. 18, n. 52, p. 17-28, 2004.

PIERUCCI, Antonio Flávio. Ciências Sociais e a religiáo: a religião como ruptura. In: TEIXEIRA, Faustino; MENEZES, Renata. As religiöes no Brasil: continuidades e rupturas. Petrópolis: Vozes, p. 17-34, 2006.

RODRIGUES, Denise dos Santos. Os sem religião nos censos brasileiros: sinal de uma crise do pertencimento institucional. Horizonte, v. 10, n. 28, p. 1130-1153, 2012.

SANCHIS, Pierre. Catolicismo: Modernidade e Tradição. São Paulo: Loyola, 1992

SANCHIS, Pierre. As religiōes dos brasileiros. Horizonte, v.1, n.2, p. 28-43, 1997.

SANCHIS, Pierre. As Ciências Sociais da religiáo no Brasil. Debates do NER, Porto Alegre, ano 08, n. 11, p. 7-20, 2007.

SANCHIS, Pierre. Pluralismo, transformação, emergência do indivíduo e de suas escolhas. Line, ago, 2012. Disponível em: <http://www.IHUOn-ihu. 
unisinos.br/entrevistas/512850-pluralismo-transformacao-emergencia--doindividuo-e-de-suas-escolhas $>$. Acessado em: 13 de junho de 2020.

SANCHIS, Pierre. Prefácio. In: TEIXEIRA, Faustino; MENEZES, Renata. Religióes em movimento: o Censo de 2010. Petrópolis: Vozes, p. 11-16, 2013. SANTOS, Maria Goreth. Os limites do Censo no campo religioso brasileiro. Religióes em conexão: números, direitos, pessoas - Comunicaçôes do ISER, Rio de Janeiro, n. 69, p. 18-33, 2014.

STEIL, Carlos Alberto. Pluralismo, modernidade e tradição: transformaçōes do campo religioso. Ciências Sociais e Religiäo, ano 3, n. 3, p. 115-129, 2001. STEIL, Carlos Alberto. Mapas e hologramas como metáforas para pensar os dados sobre religião no censo do IBGE de 2010. Debates do NER, Porto Alegre Ano 14, n. 24, p. 29-37, 2013.

TEIXEIRA, Faustino. Os dados sobre religiôes no brasil em debate. Debates do NER, Porto Alegre, ano 14, n. 24, p. 77-84, jul./dez, 2013 a.

TEIXEIRA, Faustino. O censo de 2010 e as religiōes no Brasil: esboço de apresentação. In: TEIXEIRA, Faustino; MENEZES, Renata. Religiōes em movimento: o Censo de 2010. Petrópolis: Vozes, 2013b, p. 17-36.

TEIXEIRA, Faustino. Campo religioso em transformaçâo. Religióes em conexão: números, direitos, pessoas - Comunicaçôes do ISER, Rio de Janeiro, n. 69, p. 34-45, 2014.

Sites e Blogs

VIANNA, Sérgio Besserman. 2002. Retratos do Brasil. Vou te Contar. A Revista do Censo. Rio de Janeiro n. 7, agosto. Disponível em: https://biblioteca. ibge.gov.br/visualizacao/periodicos/154/vtc_2002_n7_ago.pdf. Acesso em: IBGE. Disponível em: https://memoria.ibge.gov.br/sinteses-historicas/ historicos-dos-censos/censos-demograficos.html. 
G1. Mais de um terço de unióes no país é consensual sem casamento, diz IBGE. Disponível em: http://g1.globo.com/brasil/noticia/2012/10/mais-de-um-terco-de-unioes-no-pais-e-consensual-sem-casamento-diz-ibge.html. Acesso em: 04, dez. 2020.

Recebido em: 27/07/2020

Aprovado em: 30/09/2020 



\section{ENSAIO FOTOGRÁFICO}


